Faculdade

de Ciências Econômicas UFRGS
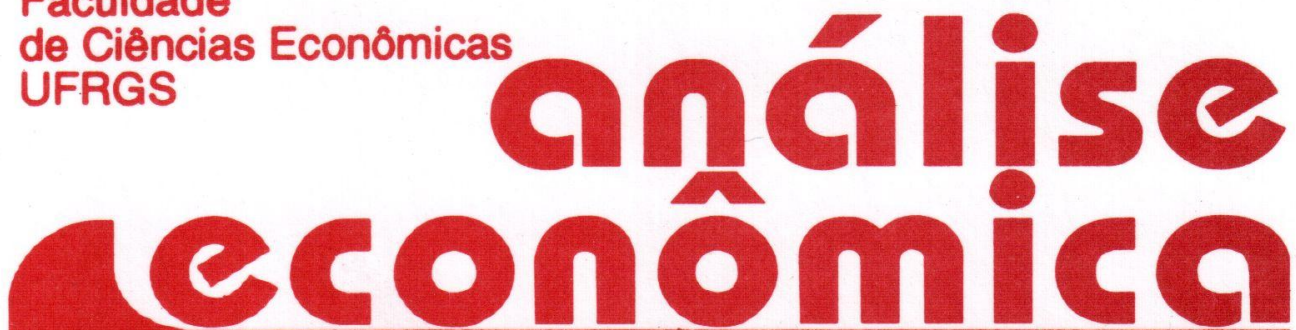

- SIDERURGIA E O PARADIGMA TECNOLÓGICO

Angela Maria Morandi

- ESTIMATING PRIVATE DEMANDS FOR PUBLIC GOODS

Eduardo Pontual Ribeiro

- KEYNES E A ATUALIDADE DA TEORIA KEYNESIANA

Fernando Ferrari Filho

- IMPRODUTIVIDADE DE UM CONCEITO DE PRODUÇÃO Raul Cristóvão dos Santos

- A NEGAÇÃo dA INEFICÁCIA DA POLÍTICA MONETÁRIA João Sicsú

- DESREgulamentAÇÃo, globa LIZAÇÃo E A CADEIA DO TRIGO Lena Lavinas

Manoel Magina

- ALUGUÉIS RESIDENCIAIS EM PORTO ALEGRE

Marco Aurélio Stumpf González

- POLICY INTERVENTION AND THE TRADE-OFF BETWEEN GROWTH AND DISTRIBUTION OF INCOME Joanílio Rodolpho Teixeira Jorge Thompson Araujo

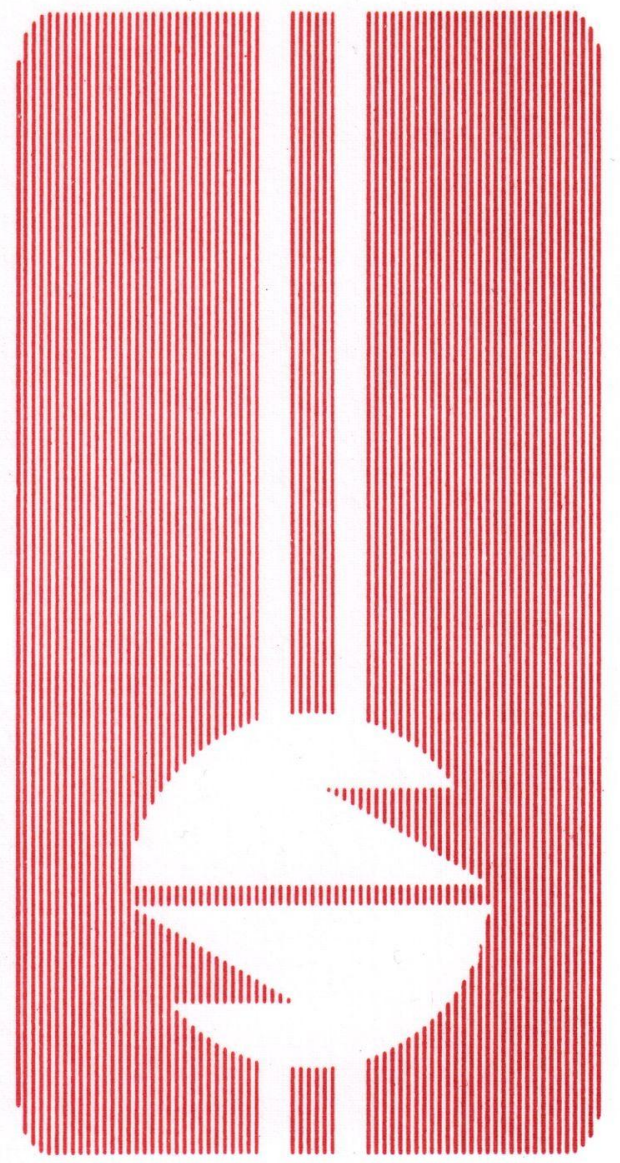


UNIVERSIDADE FEDERAL DO RIO GRANDE DO SUL

Reitora: Prof ${ }^{a}$. Wrana Maria Panizzi

FACULDADE DE CIENNCIAS ECONÓMICAS

Diretora: Prof ${ }^{\mathrm{a}}$. Otilia Beatriz Kroeff Carrion

CENTRO DE ESTUDOS E PEQUISAS ECONÔMICAS

Diretor. Prof. Fernando Ferrari Filho

DEPARTAMENTO DE CIÊNCIAS ECONÓMICAS

Chefe: Prof. Gentil Corazza

CURSO DE PÓS-GRADUAÇÃO EM ECONOMIA

Coordenador. Prof. Marcelo Savino Portugal

CURSO DE PÓS-GRADUAÇÃO EM ECONOMIA RURAL

Coordenador: Prof. Carlos Guilherme A. Mielitz Netto

CONSELHO EDITORIAL: Achyles B. Costa, Aray M. Feldens, Carlos A. Crusius, Carlos G. A. Mielitz Netto, Eduardo A. Maldonado Filho, Eduardo P. Ribeiro, Eugênio Lagemann, Fernando Ferrari Filho, Gentil Corazza, Marcelo S. Portugal, Nali J. Souza, Otília B. K. Carrion, Paulo A. Spohr, Paulo D. Waquil, Pedro C. D. Fonseca, Roberto C. Moraes, Ronald Otto Hillbrecht, Stefano Florissi, Eleutério F. S. Prado (USP), Fernando H. Barbosa (FGV/RJ), Gustavo Franco (PUC/RJ), João R. Sanson (UFSC), Joaquim P. Andrade (UnB), Juan H. Moldau (USP), Paul Davidson (Univ. of Tennessee), Werner Baer (Univ. of Illinois).

COMISSÃO EDITORIAL: Eduardo Augusto Maldonado Filho, Fernando Ferrari Filho, Gentil Corazza, Paulo Dabdab Waquil, Marcelo Savino Portugal, Roberto Camps Moraes.

EDITOR: Nali de Jesus de Souza

SECRETARIA: Cláudia Porto Silveira, Sandra Mascarello e Fábio Régis Sparremberger. Revisão de textos: Vanete Ricacheski.

FUNDADOR: Prof. Antônio Carlos Santos Rosa

Os materiais publicados na revista Análise Económica são da exclusiva responsabilidade dos autores. É permitida a reprodução total ou parcial dos trabalhos, desde que seja citada a fonte. Aceita-se permuta com revistas congêneres. Aceitam-se, também, livros para divulgação, elaboração de resenhas e recensões. Toda correspondência, material para publicação (vide normas na terceira capa), assinaturas e permutas devem ser dirigidos ao seguinte destinatário:

PROF. NALI DE JESUS DE SOUZA

Revista Análise Econômica - Av. João Pessoa, 52

CEP 90040-000 PORTO ALEGRE - RS, BRASIL

Telefones: (051) 316-3348 e 316-3440 - Fax: (051) 316-3990

nali@vortex.ufrgs.br 


\title{
POLICY INTERVENTION AND THE TRADE - OFF BETWEEN GROWTH AND FUNCTIONAL DISTRIBUTION OF INCOME
}

\author{
Joanilio Rodolpho Teixeira* \\ Jorge Thompson Araujo
}

\begin{abstract}
In opposition to the dominant view that treats growth and distribution as conflicting goals, one can counterargument with the claims of some scope for complementarities among them. This paper constructs a model intended to demonstrate that if tax policy is manipulated to ensure that a higher saving ratio is compatible with a greater workers' share in income, a reduction in the degree of distributional inequality can be consistent with faster growth. We are concerned only with the functional distributions of income and the structural form of our model is based on some relevant features of the contributions associated with postKeynesians economists.
\end{abstract}

AEA Code: 912 Key Words: Growth, functional distribution, trade-off, equity.

\section{SINOPSE}

Formulamos um modelo pós-Keynesiano que busca reduzir o conflito entre crescimento e distribuição funcional da renda Mostramos que se a política fiscal pode ser manipulada de modo a assegurar que a taxa de poupança varie inversamente com a participaçăo dos capitalistas na renda, uma redução no grau de desigualdade distributiva pode ser consistente com uma maior taxa de crescimento.

Cód. AEA: 912 Palavras-chave: crescimento, distribuição funcional, eqüidade.

\footnotetext{
"Professor of Economics, University of Brasilia.
}

Economist, World Bank, Washington, D.C. The views expressed in this article are of the authors only, and do not necessarily coincide with those of The World Bank, its Executive Directors, or the countries they represent.

\begin{tabular}{|l|l|l|l|l|}
\hline ANÁLISE ECONÔMICA & ANO 15 & N. 28 & Setembrol97 & p. 148 - 158 \\
\hline
\end{tabular}




\section{THEORETICAL FRAMEWORK}

It is often argued that any attempt to redistribute income from profits to wages would reduce total savings and investment, and thus decrease the rate of growth. Actually, there is little in the way of recent historical research to sustain that the relationship between growth and distribution is a very simple one.

In this paper we design a post-Keynesian model based on a combination of some relevant features of Harrod-Domar and KaldorPasinetti models to deal with such controversy. Our approach includes a number of parameters, variables and definitional equations to describe: taxes, transfers, public debt, foreign trade etc., to specify such conflict. If, however, fiscal policy can be used to ensure that the savings rate (aggregate) varies inversely with capitalists'share in income then such trade-off is overcomed. This theoretical possibility is obtained through compensatory changes in some macroeconomics instruments of economic policy, once the issues are phrased in terms of specific targets and specific tools of redistribution.

The structure of this paper is as follows: In this section we examine the theoretical framework involving the so called conflict between growth and distribution. Section 2 contains the analytical core of our contribution. The structural model is presented as well as its solution, comparative statics and two examples of alternative policies. Section 3 discusses the interpretation and the validity of our results.

Assuming that there is a given technique represented by a constant (maximum) technical output - capital ratio, $(\sigma=Y / K$, if the average saving propensity of the economy is $s$, then the Keynesian condition $(S=I)$ implies that the growth rate is:

$$
g_{w}=I / K=S / K=s Y / K=s \sigma
$$

This is the well known Harrod - Domar result. The warranted growth rate, $g_{w}$, is fully determined by $s$ and $\sigma$, and, unless one of these two variables adjusts appropriately, gw will not be equal to the natural growth rate, $g_{n}$, except by chance.

Dealing with economic policy, for a "desired $\sigma$ " one can stablish "locus of equilibria", points $\left(g_{w}, s\right)$, given by expression (1.1) and its validity is not restricted to steady growth paths. Obviously, outside the warrant growth trajectory the interpretation of equation (1.1) changes - i.e., while the steady growth value of gw is determined by exogenous values of $s$ and $\sigma$, causality is reversed in any short period. Thus, the rate of investment (capital accumulation) is the exogenous variable which determines $\sigma$ and, a priori, 
there is no presumption that investors will choose investment levels compatible with the requirements of $g_{w}$.

The instability of the warranted growth path and the discrepancy between warranted and natural growth rates are serious problems which in Harrod's view could only be overcome through determined policy intervention, but he does not contemplate an important problem - the distributional effects of such intervention.

There are many hypotheses relating to the saving function which would make s variable. Kaldor (1955-6) takes his starting point from Harrod (1936), but recognizes the importance of contemplating distributional aspects to deal with growth and stability for a long-run, fully employed steady path. He assumes that savings of wage-earners and profit-receivers are functions of their income. However, the lather's propensity to save is higher than the former's, so that the overall savings-income ratio depends on the distribution of income.

Is his model, income $(Y)$ is divided into wages $(W)$ and profits $(P)$. Investment $(I)$ is inscribed as equal to savings (S), being saving propensities for capitalists (sc) and workers (sw) constrained by $1>\mathrm{sc}>\mathrm{sw}>0$. Simple algebraic manipulation shows that:

$$
\begin{aligned}
& I=s_{x} P+s_{w} W=s_{c} P+s_{w}(Y-P)=\left(s_{c}-s_{w}\right) P+s_{w} Y \\
& \left(P / Y=\left[1 /\left(s_{c}-s_{w}\right)\right] I / Y-s_{w} /\left(s_{c}-s_{w}\right)\right.
\end{aligned}
$$

The "interpretative value" of Kaldor's model lies on the Keynesian hypotheses that investment, or rather the ratio of investment to output, can be treated as an independent variable invariant with respect to changes in the two savings propensities, as pointed out by Skott (1989) Expression(1.3) can be restated as:

$$
\mathrm{s}=\mathrm{i}=\left(\mathrm{s}_{c}-\mathrm{s}_{\mathrm{w}}\right) P / Y+\mathrm{s}_{\mathrm{w}}
$$

where $i$ is the participation of investment in the national income.

Connecting Harrod's formula (1.1) to the Kaldorian function (1.4) we obtain:

$$
g_{w}=\sigma\left[s_{w}+\left(s_{c}-s_{w}\right) P M\right]
$$

Ceteris paribus, $\partial \mathrm{g}_{\mathrm{w}} / \partial(\mathrm{P} / \mathrm{Y})=\sigma\left(\mathbf{s}_{\mathrm{c}}-\mathbf{s}_{\mathrm{w}}\right)>0$ and $\partial \mathrm{g}_{\mathrm{w}} / \partial(\mathrm{W} / \mathrm{Y})=$ $-\sigma\left(\mathbf{s}_{\mathrm{C}}-\mathbf{s}_{\mathrm{w}}\right)<0$, since $P / Y+W / Y=1$.

This conflict between growth and distribution extends to the Pasinetti's (1962) approach in which i) worker's earnings comprise wages $(W)$ and profits $\left(P_{w}\right)$ as interest on loans to capitalists; ii) capitalists earn only profits 
$\left(P_{c}\right)$ where $P_{c}+P_{w}=P$; and iii) worker's savings out of their total income (W $\left.+P_{w}\right)$ is a constant fraction $S_{w}$. Thus:

$\mathbf{g}_{\mathrm{w}}=\sigma\left(\mathbf{S}_{\mathrm{w}} \mathbf{y}_{\mathrm{w}}+\mathbf{s}_{c} \mathbf{y}_{c}\right)$, where $\mathbf{y}_{\mathrm{w}}=\left(\mathbf{W}+\mathbf{P}_{\mathrm{w}}\right) / \mathrm{Y}$ and $\mathbf{y}_{c}=\mathbf{P}_{\mathrm{c}} \mathbf{Y}$

As $y_{c}=1-y_{w}$ and $s_{c}>s_{w}$, then $\partial g_{w} / \partial y_{w}<0$ and $\partial g_{w} / \partial y_{c}>0$

This shows the trade-off between growth and distribution in a closed economy, without significant government participation. Of course, this approach only deals with inequality between social classes. It is not concerned with the size distribution. The link between the two concepts raises many questions. To proceed, we assume the case of zero withinclass inequality.

We have also opted for starting directly with macroeconomic relationships representing stylized facts, which are very much in the postKeynesian and neo-Structuralist traditions, instead of specifying an intertemporally optimizing framework to determine the saving and growth rates. Observe, however, that the structure of our model is fully consistent with some recent findings of the so-called "New Growth Theory". Bertola (1994, p.9) shows how the endogenously determined saving rate is negatively correlated with the share of wages in national income. He claims that "Kaldorian assumptions hold in their purest form in an endogenously growing economy where savings decisions are taken by infinitely-lived individuals (or dynasties)".

\section{NOTATION AND THE MODEL}

Our post-Keynesian model of growth with distributional improvements for open economies involves effective governmental activities. To proceed in this direction we introduce into the model some elements pointed out by Pasinetti (1989) and Werneck (1987). For the microfoundation of our approach see Baranzini (1991) and for consideration concerning international trade, allowing a nonzero current/capital account balance, see Teixeira (1991).

Our extension to a Kaldor-Pasinetti type model assumes an economy already operating at full employment which, through government intervention, negotiates the jumps from one steady-state growth path to another. ${ }^{\dagger}$ Among other things it shows that there are definite limits to which

\footnotetext{
${ }^{1}$ As pointed out by Harris $\left(1993\right.$, p. 67), ${ }^{\prime \prime}(\ldots)$ in the real world of actually functioning capitalist economies, growth takes place always in cycle of boom and bust with a margin of ununtilized capacity as well as a reserve army of unemployed labour". We consider our model only a first approximation to the problems of equity and growth in a kind of stylized world.
} 
the functional income distribution may improve. Our aim is to show such possibility. The notation is standard:

$Y_{n}=$ Gross National Product

$Y=$ Gross Domestic Product

$X_{n f}=$ Exports of goods and non-factor services

$M_{n f}=$ Imports of goods and non-factor services

$Y_{f}=$ Net income sent abroad

$M-X=M_{n f}-X_{n f}-Y_{f}=$ Deficit in current account

$Y^{\prime}=$ Disposable income of the private sector

$Y_{w}=$ Disposable income of the workers

$Y_{\mathrm{c}}=$ Disposable income of the capitalists

$W=$ Total wage bill

$P=$ Total profits

$P_{w}=$ Worker's profits

$P_{c}=$ Capitalists profits( net of $J_{p f}$, see below)

$P_{\mathrm{e}}=$ Gross profits accruing to public enterprises

$S=$ Total saving

$S^{\prime}$ = Saving of the private sector

$S_{\mathrm{w}}=$ workers' saving

$\mathrm{S}_{\mathrm{C}}=$ Capitalist'saving

$S_{\text {pub }}=$ Public sector's saving

$\mathrm{S}_{\mathrm{g}}=$ Saving of the government in current account

$S_{\mathrm{e}}=$ Public enterprises' profit retentions

$\mathrm{C}=$ Aggregate consumption

$G=$ Current government expenditure

SUB $=$ Subsidies

$T_{r}=$ Government transfers to workers

CUST $=$ Consumption of the government

$T=$ Total taxes

$T_{d}=$ Direct taxes

$T_{i}=$ Indirect taxes (net of subsidies)

$t_{p}=$ Proportional tax rate on profits

$t_{w}=$ Proportional tax rate on wages

$S_{e}=$ retention (saving) rate of the public enterprise

$J_{m}=$ Services (interest) on government's domestic debt

$J_{e}=$ Services (interest) on the domestic debt of public companies

$J_{\mathrm{gf}}=$ Services (interest) on the foreign debt of the government

$J_{\mathrm{ef}}=$ Services (interest) on foreign debt of public enterprises

$J_{\mathrm{pf}}=$ Services (interest) on foreign debt of the private sector (by assumption deduced from the capitalists' profits)

$J_{b}=$ Services (interest) on private deposit in foreign currency in the Central Bank 
$\mathrm{g}_{\mathrm{w}}=$ Potencial( warranted) rate of grouth of the gross domestic product

The following equations and identities are self-explanatory in our model, where indirect taxes are exogenous:

$$
\begin{aligned}
& Y_{n}=C+I+G+X-M \\
& X-M=X_{n f}-M_{n f}-Y_{f} \\
& Y=Y_{n}+Y_{f}=C+1+G+X_{n f}-M_{n f} \\
& Y_{f}=J_{g f}+J_{p f}+J_{e f} \\
& Y_{c}=\left(1-t_{p}\right) P_{c} \\
& Y_{w}=\left(1-t_{w}\right) W+\left(1-t_{p}\right) P_{w}+T_{f} \\
& S_{c}=S_{c}\left(1-t_{p}\right) P_{c} \\
& S_{w}=S_{w}\left[\left(1-t_{w}\right) W+\left(1-t_{p}\right) P_{w}+T_{f}\right] \\
& T=t_{w} W+t_{p} P+T_{i} \\
& P_{e}^{*}=P_{e}-J_{e}-J_{e f} \\
& S_{g}=t_{w} W+t_{p} P+T_{i}-G-\left(J_{m}+J_{g f}+J_{b}\right) \\
& S_{e}=S_{e}\left(1-t_{p}\right)\left(P_{e}-J_{e}-J_{e f}\right) \\
& S_{p u b}=S_{g}+S_{e} \\
& S^{\prime}=S_{w}+S_{c} \\
& G=T_{f}+S_{B}+C U S T \\
& S^{\prime}=S^{\prime}+S_{p u b}+M-X
\end{aligned}
$$

The solution of our model, below, provides a broad and flexible framework into which aims of economic policies could be fitted and related to one another:

$$
\begin{aligned}
Y^{\prime}= & Y_{c}+Y_{w}=Y-\left(T-J_{m}-J_{g f}-J_{b}\right)-s_{e}\left(1-t_{p}\right) P_{e}{ }^{*}-Y_{f} \\
S^{\prime}= & s_{c}\left[Y-\left(T-J_{m}-J_{g f}-J_{b}\right)-s_{e}\left(1-t_{p}\right)\left(P_{e}-J_{e}-J_{e f}\right)-Y_{f}-Y_{w}\right]+s_{w} Y_{w} \\
S= & s_{c} Y+\left(1-s_{c}\right)\left[T-J_{m}-J_{b}+s_{e}\left(1-t_{p}\right)\left(P_{e}-J_{e}-J_{e f}\right)\right]-s_{c}\left(J_{p f}+J_{e f}\right)+ \\
& M-X-\left(s_{c}-s_{w}\right) Y_{W}-\left(T_{r}+S U B+C U S T\right)
\end{aligned}
$$

Dividing (2.19) by $Y$ we obtain the aggregate saving rate:

$$
\begin{aligned}
s= & s_{c}+\left(1-s_{c}\right)\left[t-j_{m}-j_{g f}+j_{b}+s_{e}\left(1-t_{p}\right)\left(p_{e}-j_{e}-j_{e f}\right)\right]-s_{c}\left(j_{p f}+j_{e f}\right)+ \\
& m-x-\left(s_{c}-s_{w}\right) y_{w}-\left(t_{f}+\text { cust }+s u b\right)
\end{aligned}
$$


where the small letters and symbols indicate the original variable (represented by capital letters) divided by $Y$ where appropriate. All variables are stated in constant "real" value in a given monetary base.

From (2.9) we obtain a proxy for the gross burden of taxation:

$$
t=t_{w} w+t_{p}\left(p_{w}+p_{c}+p_{e}\right)+t_{i}
$$

The potential (warranted) growth rate is:

$$
\begin{gathered}
g_{w}=\sigma\left\{s_{c}+\left(1-s_{c}\right)\left[t-j_{m}-j_{g f}-j_{b}+s_{e}\left(1-t_{p}\right)\left(p_{e}-j_{e}-j_{e f}\right)\right]-s_{c}\left(j_{p f}+j_{e f}\right)+\right. \\
\left.m-x-\left(s_{c}-s_{w}\right) y_{w}-\left(t_{r}+\text { cust }+s u b\right)\right\}
\end{gathered}
$$

When $t$ and $y$ are explicited we obtain:

$$
\begin{aligned}
g_{w}= & \sigma\left\{s_{c}+\left(1-s_{c}\right)\left[t_{w} w+t_{p}\left(p_{w}+p_{c}+p_{e}\right)+t_{i}-j_{m}-j_{g f}-j_{b}+\right.\right. \\
& \left.s_{e}\left(1-t_{p}\right)\left(p_{e}-j_{e}-j_{e f}\right)\right]-s_{c}\left(j_{p f}+j_{e f}\right)+m-x-\left(s_{c}-s_{w}\right)\left[\left(1-t_{w}\right) w+\right. \\
& \left.\left.\left(1-t_{p}\right) p_{w}+t_{r}\right]-\left(t_{r}+\text { cust }+ \text { sub }\right)\right\}
\end{aligned}
$$

After this sequence of algebraic manipulation we arrived at the result that, given the saving propensities of workers and capitalists, the effect of labour's share of national income on the growth rate will depend, in some complicated way, on government tax policy.

The comparative statics is given by signs of the partial derivatives of $g_{w}$ with respect to some variables and parameters. The intuitive rationale for the signs of the partial derivatives is not difficult to fathom.
a) Saving parameters:
$\mathrm{S}_{\mathrm{C}} \quad \mathrm{S}_{\mathrm{w}} \quad \mathrm{S}_{\mathrm{e}}$

$(+)$

provided that $\mathrm{y}_{\mathrm{c}}>\mathrm{j}_{\mathrm{gf}}$ and $\mathrm{p}_{\mathrm{e}}{ }^{*}>0$

b) Tax parameters: $\quad t \quad t_{w} \quad t_{p}$

provided that $\left(1-s_{c}\right)\left(p_{w}+p_{c}+p_{e}\right)+\left(s_{c}-s_{w}\right) p_{w}>s_{e} p_{e}^{*}$

c) Domestic (public) debt parameters: $j_{m} \quad j_{e}$

$(-) \quad(-)$

d) Foreign debt parameters:

$\mathrm{j}_{\mathrm{gf}} \quad \mathrm{j}_{\mathrm{ef}} \quad \mathrm{j}_{\mathrm{pf}}$

$(-)$

$(-)$

$(-)$

e) Government expenditure parameters: $\quad G / Y \quad t_{r}$

f) Distributive parameters: $\quad y_{w} \quad w \quad p_{w}$

$(-) \quad(-) \quad(-)$

provided that $\left(1-s_{w}\right) t_{w}>s_{c}-s_{w},\left(1-s_{w}\right) t_{p}>s_{c}-s_{w}$ and $s_{c}>s_{w}$. 
To show that faster growth is consistent with distributional improvements it will be sufficient to consider two examples of alternative economic policies:

i) Assume, ceteris paribus, that:

$$
d g_{w}=\left(\partial g_{w} / \partial y_{w}\right) d y_{w}+\left(\partial g_{w} / \partial t\right) d t
$$

that is to say, an attempt is made to allow for a higher warranted growth rate through a heavier gross burden of taxation ( $d t>0$ ), at the same time that a distributional improvement toward wage-earners ( $d y_{w}>0$ ) through, say, a non - inflationary money - wage increase for a given level of output, ${ }^{2}$ is implemented. Such a policy will be successful whenever the two absolute variations $d t$ and $d y_{w}$ follow the simple rule below:

$$
\begin{aligned}
& \left(\partial \mathbf{g}_{w} / \partial t\right) d t>-\left(\partial \mathbf{g}_{w} / \partial \mathbf{y}_{w}\right) d \mathbf{y}_{w} \\
& \mathrm{dt}>\left\{\left(\mathbf{s}_{c}-s_{w}\right) /\left(1-s_{c}\right)\right\} d \mathbf{y}_{w}
\end{aligned}
$$

Given that $s_{c}>s_{w}$, this condition will be all the more stringent the higher is the capitalists' propensity to save $\left(\mathrm{s}_{\mathrm{c}}\right)$ : the reduction in capitalists' saving due a larger $y_{w}$ is greater the higher is $s_{c}$, generating the need for a relatively large increase in $t$, which may not be politically viable.

ii) Assume, now, that:

$$
d g_{w}=\partial\left(g_{w} / \partial \mathbf{y}_{w}\right) y_{w}+\left(\partial g_{w} / \partial t\right) d t+\Sigma\left(\partial g_{w} / \partial j_{i f}\right) d j_{i f}, i=p, e, f
$$

so that the task of increasing $g_{w}$ and $y_{w}$ simultaneously with a heavier gross burden of taxation may be facilitated, provided that other leakage's from the process of saving formation, e.g. the interest payments on external debt per unit of output, are restrained. In this case, the increase in t may be smaller, as the aggregate saving rate will increase with the lower interest payments. Formally, if $d y_{w}>0, d t>0$, and $d j_{p f}<0, d j_{e f}<0, d j_{g f}<0$, then $d g_{w}>0$ only if $\mathrm{dt}>\left[\left(\mathrm{s}_{\mathrm{c}}-\mathrm{s}_{\mathrm{w}}\right) /\left(1-\mathrm{s}_{\mathrm{c}}\right)\right] \mathrm{dy} \mathrm{y}_{\mathrm{w}}-1 /\left(1-\mathrm{s}_{\mathrm{c}}\right) \Sigma\left(\partial \mathrm{g}_{\mathrm{w}} / \partial \mathrm{j}_{\mathrm{fi}}\right) \mathrm{d} \mathrm{j}_{\mathrm{jf}}, \mathrm{i}=\mathrm{p}, \mathrm{e}, \mathrm{f}$.

These two examples illustrate the possibility of generating aggregate saving rate compatible with a higher warranted rate of growth, at the same time that distributional improvements are made.

As shown above, the trade-off between growth and distribution can be overcomed in the light of two differential totals $\left(\mathrm{dg}_{w}\right.$ and $\left.d y_{w}\right)$. They can be positive simultaneously, provided that compensatory changes in other variables are attained.

\footnotetext{
2 This pressuposes a tacit agreement on the part of profit-receivers. Note this assumption is more acceptable under our hypothesis of steady growth along the warranted path.
} 


\section{INTERPRETATION AND VALIDITY OF THE RESULTS}

Our approach can be interpreted as an analysis of different equilibria solutions to the Harrodian model. If, through taxation and compensatory transfers, government is able to change the value of $s$ (the propensity to save) in such a way that it varies inversely with capitalists' share in income, there is no inconsistency between growth and distributional improvements. Figure 1 illustrates the core of our argument. Notice that $g_{w}=\sigma s$ represents the "locus" of different solutions of Harrod's model for a given $\sigma$, due to change in the values of $g_{w}$ and $s^{3}$

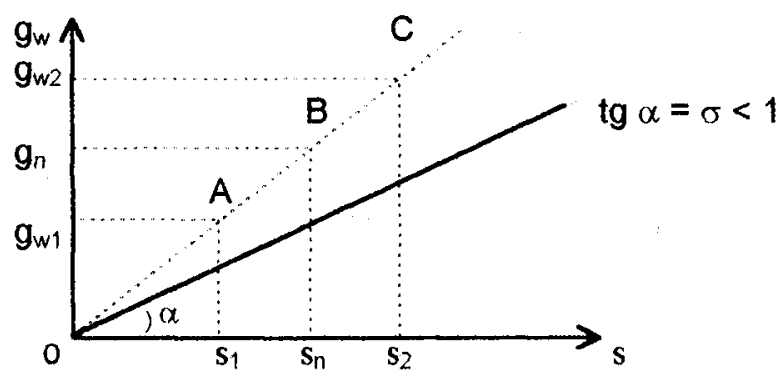

Figure 1 - The locus of solutions

The area formed by the triangle $O s_{n} B$ in Figure 1 represents the region of validity for our proposal. Being $s_{n}$ the savings rate associated to the natural growth rate, if $s<s_{n}$ and $g_{w}<g_{n}$ we have the region in which there is insufficient saving. For instance, $s_{1}<s_{n}$ and $g_{w 1}<g_{n}$ (point $A$, path $y(t)=y(0)$ $\left.\exp g_{w 1} t\right)$. Naturally, if $s_{w}>s_{n}$ and $g_{w}>g_{n}$ there is no reason to expand $g_{w}-$ actually it should be reduced. This is the case where $s_{2}>s_{n}$ and $g_{w 2}>g_{n}$ (point C, path $y(t)=y(0) \exp g_{w_{2}} t$ ).

Needless to say that, ceteris paribus, contractionary policies (reduction in public expenditure, expansion of taxation, etc.) increases $s$ and $g_{w}$. However, turning to changes in saving behavior, the result may well be a standard Keynesian "paradox of thrift" - economic growth (in terms of effective growth rate) is not stimulated with an expansion of the savings rate. This possibility is shown in Figure 2.

In our model, the savings function for both capitalists and workers are established on the assumption of validity of the Ricardian equivalence

\footnotetext{
${ }^{3}$ A movement from point $A$ to $C$, in Figure 1, represents a change from a given warranted path to another and not on the same trajectory
} 
theorem ( $j_{n}$ and $j_{e}$ do not enter in those saving functions) and this assumption needs further enquire. See Visaggio (1989).

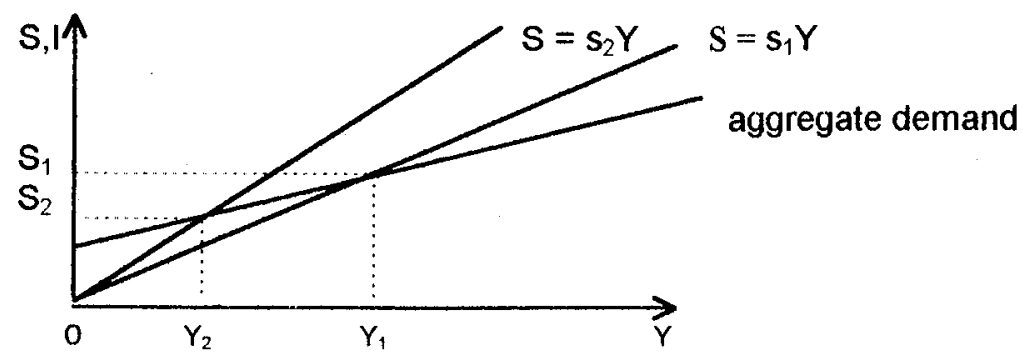

Figure 2 - The paradox of Thrift $\left(s_{1}<s_{2}\right)$

To suggest comparison between pre-fisc and post-fisc income obtained by workers and capitalists, i.e., before and after the adoption of redistributive policies, according to Woodfield and McDonald (1979,p. 331), we now define two distributional variables $z$ and $z^{0}$. The first $\left(z=Y_{w} / Y_{c}\right)$ denotes the ratio of workers' disposable income to capitalists' disposable income and the latter $\left(z^{0}=Y_{w}{ }^{0} / Y_{c}{ }^{0}\right)$ of pre-fisc income obtained by these social groups. There will be distributional improvements toward the workers' if $z-z>0$.

It is important to realize that there is, presumably, an acceptable defined level of taxation and transfers if the social system is to continue to have a normal existence (see Steedman, 1972, p. 1392). Within the limits of the political environment, the policy maker's aim is to find an outer boundary to the combinations of instrumental variables which are consistent with growth and distributional (functional) improvements. Of course, our approach only deals with inequality between social classes. In this sense, the overall behaviour of the inequality-growth relationship is in general ambiguous. To solve the ambiguity one needs to check by direct calculation the link between the functional and the size distribution of income. This will depend in part on how much profit and wage income are concentrated within each social group. Some may argue that a sharp division between these two concepts (size distribution and functional distribution) logically cannot be made because they are actually indissolubly mixed. This argument raises important points left for further research.

It is also possible to argue that our approach involves too many equations and identities for a model that is meant to establish a hinterto unrecognized theoretical point: to capture the economic context in which growth with distributional improvements (functional) may take place. 
However, we are a bit skeptical ourselves about approaches that starting from a very simplified construction adds complications at a later stage. From the methodological standpoint, we consider more meaningful to specify from the beginning those analytical features which we consider essential.

To conclude, our model is specified in a way that incorporates some important features of mixed economies. Despite some obvious limitations ${ }^{4}$ it shows the theoretical possibility of conciliating growth and distributional improvements (functional) in an open economy. This requires fiscal policy to be manipulated accordingly - a sort of tax policy would set up a positive relationship between the aggregate saving rate and workers' share of national income. We can go no further here, but it must be said that, as soon as we move away from equilibrium analysis and become also concerned with the link between the functional and size distribution of income, many difficulties arise. Most of then have yet to be solved in economic theory.

\section{REFERENCES}

BARANZINI, M A. Theory of Wealth Distribution and Accumulation. Oxford Oxford University Press, 1991

BERTOLA, G. Wages, Profits and Theories of Growth. In PASINETTI, L and SOLOW, $K$ (eds.) Economic Growth and the Structure of Long-Term Development. Saint Martin's Press, 1994

HARROD, R. An Essay in Dynamic Theory. Economic Journal, 1939

HARRIS, D Economic Growth and Equity: Complements or Opposites? The Review of Black Political Economy, Winter, 1993

KALDOR, N Alternative Theories of Distribution. Review of Economic Studies, 1955-6.

PASINETTI, L. The Rate of Profit and Income Distribution in Relation to the Rate of Economic Growth Review of Economics Studies, 1962

Ricardian Debt/Taxation Equivalence in the Kaldor Theory of Profits and Income Distribution. Cambridge Journal of Economics, 1989

SKOTT, P. Conflict and Effective Demand in Economic Growth. Cambridge University Press, 1989

STEEDMAN, I. The State and the Outcome of the Pasinetti Process, Economic Journal, 1972.

TEIXEIRA, J The Kaldor - Pasinetti Process Reconsidered, Metroeconomica, 1991

VISAGGIO, M. On Ricardo's Public Debt Theory, Economic Notes, 1989

WERNECK, $R$ Retomada do crescimento e esforço de poupança: limitações e possibilidades Pesquisa e Planejamento Econômico, 1987

WOODFIELD, A \& MCDONALD, J On relative income shares in Pasinetti and Samuelson Modigliani systems, The Economic Journal, 1979.

\footnotetext{
${ }^{4}$ For instance, investment is assumed throughout to be fixed at the level required to mantain full employment, and crowding-out is dismissed as well.
} 